\title{
DA ACUMULAÇÃO DO MAGISTÉRIO COM DEMAIS CARGOS PÚBLICOS DA ÁREA JURÍDICA
}

\section{ACCUMULATION OF TEACHING WITH OTHER PUBLIC POSITIONS IN LEGAL AREA}

Reis Friede

Resumo: O presente artigo analisa a questão da acumulação do cargo de professor com os demais cargos públicos da área jurídica, sob as óticas da limitação da jornada de trabalho e da compatibilidade de horários, à luz das divergências doutrinárias e jurisprudenciais a respeito do tema, bem como da correta hermenêutica dos regramentos constitucionais e infraconstitucionais relacionados à matéria.

Palavras-chave: Acumulação. Cargo público. Professor. Área jurídica.

Abstract: This article analyzes the question of the accumulation of the teaching position with the other public positions in the legal area, in view of the limitation of the working day and the compatibility of schedules, in the light of doctrinal and jurisprudential divergences regarding the subject, as well as the correct hermeneutics of the constitutional and infraconstitutional rules related to matter.

Keywords: Accumulation. Public Office. Teacher. Legal Area.

i Desembargador Federal, Diretor do Centro Cultural da Justiça Federal (CCJF), Mestre e Doutor em Direito. Professor e Pesquisador do Programa de Mestrado em Desenvolvimento Local do Centro Universitário Augusto Motta (UNISUAM), no Rio de Janeiro. 


\section{INTRODUÇÃo}

A definição de cargo público está inserta no art. $3^{\circ}$ da Lei $n^{\circ} 8.112 / 90$. Por outro lado, utiliza-se o termo "acumulação de cargos" para designar a viabilidade constitucional do exercício simultâneo e remunerado de mais de um cargo, emprego ou função pública.

O impedimento de acumular cargos públicos lato sensu se revelou um dispositivo ora pouco respeitado, ora aplicado de forma irrazoável e com excessivo rigor. Dentre os aspectos mais polêmicos encontra-se a discussão sobre o requisito de compatibilidade de horários. Sem delimitação e conceituação expressa na Lei Maior, sobressai a importância de se elucidar o tema, particularmente no tocante ao seu alcance e efetiva aplicabilidade.

\section{DO FUNDAMENTO CONSTITUCIONAL DA ACUMULAÇÃO DE CARGOS PÚBLICOS}

Em todas as esferas da Administração Pública, a regra é a vedação da acumulação de cargos públicos, conforme expressamente dispõe a CRFB/88 em seu artigo 37, inciso XVI, com redação determinada pelas Emendas Constitucionais no 19/1998 e 34/2001.

As origens dessa vedação remetem aos tempos do Império, conforme bem colocou Meirelles, ao colacionar entendimento de José Bonifácio:

Se proíbe seja reunido em uma só pessoa mais de um ofício ou emprego, e vença mais de um ordenado, resultando manifesto dano e prejuízo à Administração Pública e às partes interessadas, por não poder de modo originário um tal empregado público cumprir as funções e as incumbências de que duplicadamente encarregado (MEIRELLES, 2008, p. 416).

Por via de consequência, é cediço concluir que o sistema constitucional brasileiro se opõe, como norma geral, às acumulações de cargos públicos. Nesse sentido, o silêncio na regência legal de acumulação não significa consentimento, pois, em se tratando de regra de exceção, toda a eventual autorização para a acumulação há de ser expressa e inequívoca.

A vedação à acumulação tem por finalidade impedir que a mesma pessoa ocupe vários cargos ou exerça várias funções e seja integralmente remunerada por todas sem, contudo, desempenhá-las com eficiência. 
Com relação aos que ocupam mandato eletivo, a Carta Magna, em seu artigo 38 e seguintes, determina que aqueles que ocupam mandato federal, estadual ou distrital devem ficar afastados de seu cargo, emprego ou função. Os prefeitos também ficam afastados de seus cargos, mas podem optar pela remuneração de qualquer um deles. Já os vereadores poderão acumular a vaga na Câmara com o cargo ou emprego público que ocupem, desde que haja demonstrada compatibilidade, caso contrário, aplica-se a mesma regra válida para os prefeitos.

Importante ressaltar que em todas as hipóteses do artigo 37, inciso VXI da CRFB/88 e no caso da acumulação por parte de vereador, deve haver, obrigatoriamente, compatibilidade de horários. Tal regra é expressamente prevista no Estatuto dos Servidores Públicos Civis da União (Lei $\mathrm{n}^{\circ}$ 8.112/90), em seu artigo 118, §2.

Podemos vislumbrar outro obstáculo para a acumulação de cargos: a incompatibilidade em razão da distância geográfica. A situação é prevista expressamente no Decreto 25031/55, do Estado de São Paulo, em seu artigo $5^{\circ}$, alínea "d". Não seria nada razoável admitir, v.g., que o mesmo servidor tivesse um vínculo no município de Santos e outro na cidade de São Paulo. A impossibilidade, no caso, decorreria de barreira fática imposta pela distância física entre as duas metrópoles.

No que se refere à utilização da licença para tratar de interesses particulares, a Lei 8.112/90 traz em seu artigo 91 a possibilidade do servidor se afastar do cargo efetivo pelo prazo de até três anos consecutivos, sem remuneração, desde que tenha completado o estágio probatório. Torna-se oportuno lembrar que tal licença é concedida no interesse da Administração, podendo também ser interrompida a qualquer tempo pela Administração ou a pedido do próprio servidor (parágrafo único do mesmo artigo).

Neste contexto, o fato do servidor estar afastado sem remuneração, não significa que poderá de per se ocupar cargos ou funções públicas sem caracterizar acúmulo de cargos, posto que o fato de se afastar de um cargo público para ingresso ou manutenção em outro cargo público não desconfigura a acumulação ilegal de cargos, nem a incompatibilidade de horário, posto que a vinculação ao cargo e a carga horária de trabalho permanecem, estando o servidor apenas licenciado (Súmula 246 do TCU).

Destarte, a acumulação de cargos públicos fora das hipóteses admissíveis configuraria, em tese, conduta que atenta contra os princípios da Administração Pública e, consequentemente, enquadrada como ato 
de improbidade administrativa, nos termos do artigo 11, inciso IX, da Lei 8.429/92 (Lei de Improbidade Administrativa).

Nessa toada, foi a própria norma constitucional que excepcionou a regra epigrafada para algumas hipóteses, mas ainda assim condicionada à necessária demonstração quanto à compatibilidade de horários, consoante disposto no artigo 37, inc. XVI da CRFB/88.

Desta feita, forçoso concluir que a possibilidade de acumulação remunerada do cargo de professor com outro cargo integrante das carreiras jurídicas (Magistratura, Promotoria, Defensoria, Advocacia Pública, Polícia Judiciária, etc.) encontra respaldo constitucional, precisamente, na alínea b, do inciso XVI, do artigo 37 supratranscrito, sendo imperioso observar os requisitos pertinentes à compatibilidade de horários e à limitação do teto remuneratório previstos no inciso XI do mesmo dispositivo.

Apesar de se falar que a regra advém do princípio da moralidade administrativa, não há fundamentos para se fixar um rol taxativo ou mesmo impossibilitar a extensão do acúmulo legal a todos os agentes providos em cargos, empregos e funções públicas, desde que haja a efetiva demonstração da compatibilidade de horário, consoante dispõe o texto constitucional vigente.

Não se pode olvidar que o êxito no concurso público é pessoal e meritório. O princípio da moralidade não fica afastado pelo fato de o servidor exercer mais de um cargo público decorrente de ato isonômico, impessoal, meritoso e disputado, que é o procedimento do concurso.

Ademais, pode-se concluir que o princípio da eficiência está umbilicalmente atrelado ao estudo da acumulação de cargos e empregos públicos, uma vez que, mesmo havendo enquadramento nas hipóteses excepcionalmente autorizadas, o acúmulo somente será lícito se ambos os ofícios forem efetivamente exercidos com a mesma presteza e com o mesmo rendimento que o seriam, se realizados isoladamente.

Observa-se, outrossim, que os destinatários da regra vedativa são aqueles investidos nos cargos públicos efetivos em geral, incluindo-se os cargos em comissionamento. A acumulação também sugere uma reflexão sobre a tecnicidade dos cargos ou empregos públicos, aspecto determinante na definição das excepcionalidades.

Podemos entender os cargos técnicos ou científicos como aqueles para cujo exercício seja indispensável a escolaridade completa em curso de nível superior, bem como aqueles para cujo exercício seja indispensável a escolaridade de, no mínimo, nível médio ( $\left.2^{\circ} \mathrm{grau}\right)$, com atribuições 
características de "técnico", sendo necessário, em todas as situações, analisar o tipo de cargo, para verificar se é acumulável com cargo de professor. Exemplo: técnico de laboratório, técnico em contabilidade etc.

Vale ressaltar que o parágrafo $10^{\circ}$ do art. 37 da CRFB/88 veda a percepção de proventos de aposentadoria com a remuneração de cargo, emprego ou função pública, com exceção da percepção de proventos de aposentadoria de servidores civis públicos e militares com a remuneração de cargo eletivo, de cargo em comissão, bem como de cargo, emprego ou função pública, neste último caso, somente quando eles são acumuláveis na ativa. No mesmo sentido, o art. 95, parágrafo único, inciso I, e $\mathrm{o}$ art. $128, \S 5^{\circ}$, inciso II, alínea "d", permitem, respectivamente, que juízes e membros do Ministério Público exerçam uma atividade de magistério.

No entanto, o art. 11 da Emenda Constitucional 20/1998 reconheceu o direito dos servidores aposentados que, até a data da sua promulgação (16 de dezembro de 1998), ingressaram novamente no serviço público por concurso público de provas ou de provas e títulos, e pelas demais formas previstas na CRFB/88, ressaltando que a acumulação só seria permitida enquanto estivessem em atividade.

\section{SANÇÕES EM CASO DE ACUMULAÇÃO ILEGAL DE CARGOS PÚBLICOS}

Constatada a acumulação ilegal de cargos e comprovada a necessária presença de má-fé do servidor, a pena a ser aplicada poderá ser a demissão; destituição ou cassação de aposentadoria; ou disponibilidade em relação aos cargos, empregos ou funções públicas em regime de acumulação ilegal. O rito a ser seguido para as apurações de acumulação irregular de cargos é determinado pela Lei no 8.112/90, em seu artigo 133.

Conforme prevê a legislação, identificada a acumulação ilegal de cargos ou a incompatibilidade de horário entre os cargos acumulados, será instaurado um processo administrativo a fim de solicitar esclarecimentos ao servidor em tal situação e, sendo constatada a irregularidade, porém, comprovada a boa-fé, o servidor deverá apresentar a opção pelo vínculo que deseja manter e aquele em relação ao qual providenciará o desligamento, situação que deverá ser comprovada mediante a apresentação de documento fornecido pelo órgão ao qual estava vinculado.

De acordo com a mais recente jurisprudência do STJ, bem como do STF, em matéria de acumulação irregular de cargos públicos, uma vez 
comprovada a efetiva prestação dos serviços e a boa-fé do servidor, estaria afastada a aplicação da Lei de Improbidade Administrativa por se tratar de mera irregularidade. Confira-se:

O reconhecimento da ilegalidade da cumulação de vantagens não determina, automaticamente, a restituição ao erário dos valores recebidos, salvo se comprovada a má-fé do servidor, o que não foi demonstrado nos autos. (STF; MS 26085, Rel. Min. CÁRMEN LÚCIA, DJU 07/04/2008)

Contudo, se consignada a efetiva prestação de serviço público e a boa-fé do contratado, deve-se afastar a violação do art. 11 da Lei n. 8.429/1992, sobretudo quando as premissas fáticas evidenciam mera irregularidade, sem elemento subjetivo convincente. Precedentes do STJ. (STJ; RESP 200902450146, Rel. Min. HERMAN BENJAMIN, $2^{\text {a }}$ Turma, DJE 23/05/2013)

A Lei n. 8.429/92 visa a resguardar os princípios da administração pública sob o prisma do combate à corrupção, da imoralidade qualificada e da grave desonestidade funcional, não se coadunando com a punição de meras irregularidades administrativas ou transgressões disciplinares, as quais possuem foro disciplinar adequado para processo e julgamento. (STJ; REsp 1.089.911, Rel. Min. CASTRO MEIRA, $2^{\mathrm{a}}$ Turma, DJE 25/11/2009)

No que tange à boa-fé, a mesma deve ser específica, ou seja, referente à vontade de exercer as duas atividades de maneira eficiente e não causar prejuízo, mesmo estando o servidor ciente de que se trata de uma eventual acumulação irregular de cargos públicos.

O segundo tópico a se analisar é se houve ou não a efetiva prestação dos serviços e se a mesma se deu de forma satisfatória, sem trazer prejuízo a nenhum dos órgãos envolvidos.

Assim, nota-se que, segundo a jurisprudência dos Tribunais Superiores, a acumulação de cargos irregular não configura necessariamente um ato de improbidade administrativa, devendo ser considerada uma série de elementos no caso concreto: se consignada a efetiva prestação de serviço público, o valor irrisório da contraprestação paga ao profissional e a boa-fé do contratado, há de se afastar a violação do art. 11 da Lei 
$n^{\circ} 8.429 / 1992$. Isso se concretiza, sobretudo, quando as premissas fáticas do acórdão recorrido evidenciam a ocorrência de simples irregularidade e inexistência de desvio ético ou inabilitação moral para o exercício do múnus público.

A Primeira Seção do STJ, no julgamento do REsp 1.244.182/ $\mathrm{PB}$, de relatoria do Ministro BENEDITO GONÇALVES, na sistemática do art. 543-C do CPC, firmou a orientação de que não é lícito efetuar desconto de diferenças pagas indevidamente a servidor ou pensionista em decorrência de interpretação errônea, equivocada ou deficiente da lei pela própria Administração Pública, ante a boa-fé do servidor público. O Supremo Tribunal Federal, por seu turno, entende que a cumulação de vantagens recebidas pela cumulação indevida de cargos públicos não importa, automaticamente, na necessidade de restituição ao Erário dos valores recebidos, pelo que se mostra imperativa a apuração da má-fé do servidor. (STJ; AGRESP 201200859052, Rel. Min. HERMAN BENJAMIN, $2^{\text {a }}$ TURMA, DJE 19/12/2012)

Na hipótese de acumulação de cargos, se consignada a efetiva prestação de serviço público, o valor irrisório da contraprestação paga ao profissional e a boa-fé do contratado, há de se afastar a violação do art. 11 da Lei n. 8.429/1992, sobretudo quando as premissas fáticas do acórdão recorrido evidenciam a ocorrência de simples irregularidade e inexistência de desvio ético ou inabilitação moral para o exercício do múnus público. (STJ; AGRESP 201100467268, Rel. Min. HUMBERTO MARTINS, $2^{\mathrm{a}}$ Turma, DJE 24/06/2011)

Há que se registrar a subjetividade da expressão valor irrisório da contraprestação paga ao profissional. O entendimento indica que trata-se de valor que não excede ao que é praticado habitualmente para serviços da mesma natureza e que não resulte em enriquecimento sem causa ou prejuízo ao erário.

Com relação aos casos em que se demonstra que houve efetivo prejuízo para a Administração Pública, como no caso da incompatibilidade de horários (que obviamente leva à conclusão de que os serviços não foram efetivamente prestados nos dois órgãos concomitantemente), não resta dúvida quanto à aplicação da Lei de Improbidade Administrativa. 
Deve-se ter em mente que a má-fé do servidor que ocupa simultaneamente dois cargos públicos, em que há incompatibilidade de horários, é nitidamente perceptível, - independentemente de outras considerações e comprovações probatórias -, uma vez que haverá necessariamente prejuízo para uma das entidades para quem o servidor presta serviços. Não se trata, portanto, a hipótese vertente, de mera irregularidade.

Detectada a qualquer tempo a acumulação ilegal de cargos, empregos ou funções públicas, a legislação pertinente prevê a notificação do servidor para apresentar opção entre os cargos em questão (artigo 133, caput, da Lei 8.112/90). Revela notar que o elemento subjetivo não está relacionado com a notificação para o exercício do direito de opção, devendo o julgador se ater somente à comprovação, ou não, do efetivo prejuízo para a Administração Pública para concluir se houve in casu boa ou má-fé.

O servidor não pode alegar desconhecimento da lei, logo não há necessidade de que haja notificação para que o mesmo tenha conhecimento da irregularidade da acumulação. Embora o $\S 5^{\circ}$, do art. 133 da Lei 8.112/90 preconize que "a opção pelo servidor até o último dia de prazo para defesa configurará sua boa-fé, hipótese em que se converterá automaticamente em pedido de exoneração do outro cargo", não resta dúvida de que a presunção de boa-fé prevista na norma restringe-se apenas ao processo administrativo disciplinar de que trata o próprio art. 133 da Lei 8.112/90 e não cabe sua aplicação nos procedimentos da Lei de Improbidade Administrativa. (SANTOS, 2017).

\section{DA PRESCRIÇÃO}

Com relação à prescrição do direito punitivo, cabe mencionar a Súmula 85 do STJ, que expressamente dispõe que "nas relações jurídicas de trato sucessivo em que a Fazenda Pública figure como devedora, quando não tiver sido negado o próprio direito reclamado, a prescrição atinge apenas as prestações vencidas antes do qüinqüênio anterior à propositura da ação".

No entanto, cumpre, outrossim, fazer algumas importantes considerações a respeito do tema vertente. $\mathrm{Na}$ forma das disposições contidas no artigo 142 da Lei n. ${ }^{\circ}$ 8.112/90, tem-se por afastada "a ocorrência de prescrição se, no momento da demissão do servidor, não tiverem transcorrido cinco anos do conhecimento dos fatos pela Administração" (STJ; MS 8928,

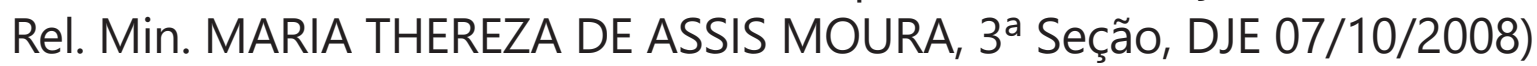


De acordo com o art. 142, inciso I, § $1^{\circ}$, da Lei $n^{\circ} 8.112 / 90$, o prazo prescricional de cinco anos, para a ação disciplinar tendente à demissão ou cassação de aposentadoria do servidor, começa a correr da data em que a Administração toma conhecimento do fato àquele imputado. (STF; RMS 24737, Rel. Min. CARLOS BRITTO)

A lei administrativa dispõe que o prazo prescricional para a ação de improbidade é o "previsto em lei específica para faltas disciplinares puníveis com demissão a bem do serviço público, nos casos de exercício de cargo efetivo ou emprego" (Lei 8.429/92, art. 23, II). Por sua vez, a Lei 8.112/90, em seu art. $142, \S 2^{\circ}$, remete à lei penal o prazo de prescrição quando as infrações disciplinares constituírem também fato-crime. Extinta a punibilidade da ora recorrente e rechaçada a deflagração de processo criminal, há de aplicar-se a regra geral, qual seja, o prazo de cinco anos previsto no art. 142, I, c/c o art. 132, IV, da Lei 8.112/90 e 23, II, da Lei 8.429/92. Ainda que se leve em conta o dia 4.1.2004 como termo inicial da prescrição, data da "ciência inequívoca do titular da demanda" - e não a data do ato ímprobo, isto é, em 17.1.2000 -, impõe-se a rejeição da exordial de improbidade pela ocorrência da prescrição, porque ajuizada a ação somente em 19.5.2010, quando já ultrapassado o lustro legal. (STJ; RESP 201201508268, Rel. Min. CASTRO MEIRA, $2^{\mathrm{a}}$ Turma, DJE 06/12/2012)

Insta salientar que as punições dos agentes públicos, nestes abrangidos o servidor público e o particular, por cometimento de ato de improbidade administrativa estão sujeitas à prescrição quinquenal (art.23 da Lei $n^{\circ}$. 8.429/92). De forma diversa, todavia, resta a ação de ressarcimento dos prejuízos causados ao erário, que é considerada imprescritível, no entendimento interpretativo do disposto no art. 37, §50, da CRFB/88 (STJ; RESP 200801330639, Rel. Min. ELIANA CALMON, $2^{\mathrm{a}}$ Turma, DJE 27/02/2009).

Justifica-se este posicionamento, uma vez que a acumulação ilegal de cargos públicos caracteriza uma situação que se protrai no tempo, motivo pelo qual é passível de ser investigada pela Administração a qualquer momento, a teor do que dispõe o art. 133, caput, da Lei 8.112/90 (STJ; MS 20148/DF, Rel. Min. ARNALDO ESTEVES LIMA, 1ª Seção, DJE 18/9/2013).

A Primeira Seção deste Superior Tribunal de Justiça, na sentada do dia 11 de setembro de 2013, no julgamento do Mandado de Segurança $n^{\circ}$ 20.148/DF, na relatoria do 
Ministro ARNALDO ESTEVES LIMA, firmou a compreensão de que não ocorre a prescrição da pretensão da Administração em adotar procedimento para equacionar ilegal acumulação de cargos públicos, mormente porque os "atos inconstitucionais jamais se convalidam pelo mero decurso do tempo". (STJ; AAGARESP 201303462854, Rel. Min. MAURO CAMPBELL MARQUES, $2^{\text {a }}$ Turma, DJE 25/08/2014)

No mais, a Corte Regional afirmou que não ocorreu a prescrição da pretensão da Administração em adotar procedimento para equacionar ilegal acumulação de cargos públicos, pois "o Estado somente tomou conhecimento da malsinada acumulação no final de 2009." (fl. 963, grifo acrescentado). Ademais, conforme dispôs o decisum agravado, a Primeira Seção do Superior Tribunal de Justiça, no julgamento do Mandado de Segurança 20.148/DF, da relatoria do Ministro Arnaldo Esteves Lima, firmou a compreensão de que não ocorre a prescrição da pretensão da Administração em adotar procedimento para equacionar ilegal acumulação de cargos públicos, mormente porque os "atos inconstitucionais jamais se convalidam pelo mero decurso do tempo". Nesse sentido: MS 20.148/DF, Rel. Ministro Arnaldo Esteves Lima, Primeira Seção, DJe 18/9/2013, e AgRg no REsp 1400398/SC, Rel. Ministro Herman Benjamin, Segunda Turma, DJe 3/2/2015. (STJ; AINTARESP 201503203271, Rel. Min.

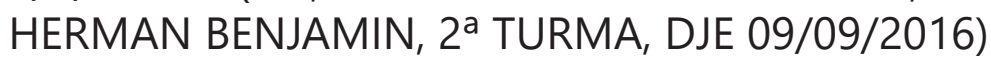

Por fim, consoante a jurisprudência do STJ, não há falar em direito adquirido à acumulação de cargos públicos nos casos em que estes não estão previstos na exceção constitucional, porquanto tal vício não se convalida com o decurso do tempo. Não há que se alegar, pois, decadência, prescrição ou coisa julgada administrativa (STJ; ADROMS 200802862493, Rel. Min. NEFI CORDEIRO, $6^{\mathrm{a}}$ Turma, DJE 05/11/2015).

\section{DA COMPATIBILIDADE DE HORÁRIOS}

Ressalte-se que a acumulação lícita de cargos exige, de forma inafastável, que se atenda o requisito da compatibilidade de horários, o que não só é expressamente exigido pela $\mathrm{CRFB} / 88$, mas igualmente pela Lei $n^{\circ} 8.112 / 90$, que regula o regime jurídico dos servidores públicos civis da União, das autarquias e das fundações públicas federais. 
A compatibilidade de horários resta configurada quando houver possibilidade de exercício dos dois cargos, funções ou empregos, em horários distintos, sem prejuízo do número regulamentar das horas de trabalho de cada um, bem como do exercício regular das atribuições inerentes a cada cargo.

Compatibilidade de horários é, ao contrário do que parece, o desencontro de horários, a inajustabilidade de horários, a descoincidência ou não de horários, ocorrida quando houver possibilidade do exercício de dois cargos, em horários diversos, sem prejuízo do número regulamentar das horas de trabalho dedicadas a cada emprego. (CRETELLA JÚNIOR, 1991, v. 4, arts. 23-37)

A grande controvérsia que se apresenta reside justamente no fato de que nem a CRFB/88, tampouco qualquer outra Lei em sentido estrito, estabeleceu de forma objetiva e taxativa como se constataria tal compatibilidade ou mesmo o eventual limite de jornada de trabalho dos servidores, implícita, - na concepção de parte expressiva da doutrina e da jurisprudência -, no regramento normativo regente.

A Advocacia-Geral da União - AGU firmou entendimento no contexto do Parecer $n^{\circ} \mathrm{GQ}$ - 145, publicado no Diário Oficial de $1^{\circ}$ de abril de 1998, pela ilicitude do acúmulo de dois cargos ou empregos públicos de que decorra a sujeição do servidor a regimes de trabalho que perfaçam o total de 80 (oitenta) horas semanais, - mesmo que demonstrada a compatibilidade de horários (em uma dimensão temporal de sete dias na semana, com 24 horas por dia, totalizando 168 horas semanais) -, entendendo que o conceito de compatibilidade de horários, admitida pelo regramento legal, somente se sustenta quando o exercício dos cargos ou empregos não exceder a carga horária de 60 (sessenta) horas semanais.

Tal recomendação seria baseada no fato de que a citada carga horária permitiria sua compatibilidade real (e não apenas ficcional) de escala de trabalho, com previsão de deslocamento de um local de trabalho para o outro e sem prejuízo do repouso reparador e do tempo de alimentação adequado, a fim de preservar a sanidade física e mental do servidor, guardando, assim, paralelo com a legislação trabalhista, a qual determina a jornada diária de trabalho em oito horas, com a possibilidade de realização de duas horas excedentes por dia, subsidiada em estudos da área laboral. 
Desta feita, ainda que com a satisfatória demonstração (teórica) de compatibilidade de horário e efetiva inexistência de jornadas de trabalho sobrepostas, não haveria, no entendimento da AGU, a perfeita adequação à autorização constitucional de acumulação de cargos públicos.

Entretanto, repise-se: nem a Carta Maior, nem a Legislação Ordinária, impuseram expressamente limites de carga horária, com o objetivo de descaracterizar categoricamente a compatibilidade de horários. Ao se seguir ipse literis o referido parecer, sem qualquer confrontação com o caso real, extrapola-se a competência regulamentadora conferida aos atos administrativos, subvertendo, assim, a hierarquia normativa do ordenamento jurídico.

Em outras palavras, a CRFB/88, ao exigir a compatibilidade de horário para a acumulação de cargo público, em nenhum de seus dispositivos limita a quantidade de horas trabalhadas, mas somente requer que uma função não seja exercida no mesmo horário que a outra. Sendo assim, não havendo tal limitação no texto constitucional, nem em qualquer diploma legal, não poderia, em tese, a Administração, através de simples Parecer Jurídico, instituir tal vedação.

Dessa forma, a compatibilização de horários é questão que se resolve caso a caso, observando-se a ocorrência, ou não, de superposição de horários. Se, do cotejo entre os horários dos respectivos cargos a serem acumulados, não se vislumbrar qualquer sobreposição, presume-se que não há comprometimento da prestação das funções desempenhadas pelo agente público, de acordo com os termos do texto constitucional.

Nesse sentido, é extensamente ampla a jurisprudência corroborativa desta hermenêutica:

(...) Inicialmente, o Superior Tribunal de Justiça (STJ), no julgamento do MS no 15.415/DF (STJ - 1a Seção - Rel. Min. Humberto Martins - julgado em 13/04/2011 - DJe de 04/05/2011), firmou o entendimento no sentido de que cumpre à Administração Pública comprovar a existência de incompatibilidade de horários em cada caso específico, não bastando tão somente cotejar o somatório de horas trabalhadas com o padrão derivado de um parecer ou mesmo de acórdão do Tribunal de Contas da União. Seguindo esta orientação, a $3^{a}$ Seção Especializada deste Tribunal tem se manifestado no sentido de que não é razoável que a Administração Pública venha a cercear um direito garantido constitucionalmente à Autora sem qualquer apuração acerca da efetiva existência 
de incompatibilidade de horários dos cargos a serem exercidos. Neste mesmo sentido, o STF, em decisão proferida pelo Ministro Roberto Barroso, nos autos do ARE 782170/PE, em 28/11/2014, se manifestou no sentido de que o Executivo não pode, sob o pretexto de regulamentar dispositivo constitucional, criar regra não prevista em lei, de modo que, ainda que a carga horária semanal dos dois cargos seja superior ao limite previsto no parecer da AGU, deve ser assegurado o exercício cumulativo de ambos os cargos públicos (TRF2; AC 0045535-18.2016.4.02.5102, Rel. Des. GUILHERME CALMON, 6 a Turma, DJe 28/08/2017).

Posse no cargo de Professor Assistente da Faculdade de Direito da Universidade Federal da Bahia, submetido à jornada de 40 horas semanais acumulando-o com o cargo de Procurador do Estado, de natureza técnico-científica, com a mesma jornada de trabalho. Não havendo norma legal regulamentando a carga horária passível de acumulação, não pode a garantia constitucional ser afastada por mera interpretação da Administração, em parecer interno. (...) Comprovado, outrossim, nos autos a compatibilidade de horários. (TRF1; AP 00139526020094013300, Rel. Des. JIRAIR ARAM MEGUERIAN, TRF1 6a Turma, e-DJF1 10/04/2013)

O STF já se posicionou algumas vezes sobre a impossibilidade de se auferir a compatibilidade de horários unicamente com base na quantidade de horas trabalhadas, confira-se:

A jurisprudência da Corte é no sentido de que a Constituição Federal autoriza a acumulação remunerada de dois cargos públicos quando há compatibilidade de horários no exercício das funções e que a existência de norma infraconstitucional que estipula limitação de jornada semanal não constitui óbice ao reconhecimento do direito à acumulação prevista no art. 37, inciso XVI, alínea c. (STF; AgRegRE 859.484, Rel. Min. DIAS TOFFOLI, 2a Turma, DJU: 12/05/2015)

(...) a administração estadual exigiu que a recorrida optasse por apenas um desses cargos, sob o fundamento de que a soma da carga horária semanal superava o limite de 65 horas (...). É lícito ao Chefe do Executivo editar decretos para dar cumprimento à lei e à Constituição. Não pode, entretanto, sob o pretexto de regulamentar dispositivo 
constitucional, criar regra não prevista, como fez o Estado do Rio de Janeiro no presente caso, fixando verdadeira norma autônoma. (STF; RE 351.905, Rel. Min. ELLEN GRACIE, $2^{\text {a }}$ Turma, DJU: DJ 09/09/2005)

O STJ igualmente já decidiu no sentido aqui defendido, verbis:

Esta Corte Superior possui entendimento no sentido de que é possível a acumulação de cargos públicos, bastando tão somente que o servidor comprove a compatibilidade entre os horários de trabalho, conforme o que preceitua o $\S 2^{\circ}$ do art. 118 da Lei 8.112/90. Não há falar em restrição quanto ao número total de horas diárias ou semanais a serem suportados pelo profissional, até porque a redação do retrocitado dispositivo está em harmonia com o que preconiza o art. 37, inciso XVI, da Constituição da República de 1988. (AgRg no AREsp 677.596/SE, Rel. Ministro HERMAN BENJAMIN, SEGUNDA TURMA, julgado em 19/05/2015, DJe 04/08/2015).

Cuida-se de Mandado de Segurança impetrado por servidor público estadual, pleiteando a acumulação de dois cargos públicos, sendo um de professor e outro de técnico de enfermagem. No caso concreto, concluiu a Administração Pública que, com a acumulação pretendida, o impetrante ultrapassaria a jornada 60 horas semanais, o que implicaria perda de eficiência no serviço público. $\mathrm{O}$ art. $37, \mathrm{XVI}$, da Constituição Federal, admite a acumulação de um cargo de professor e outro de técnico ou científico, bastando, tão somente, que o servidor comprove a compatibilidade entre os horários de trabalho. Cumpre à Administração Pública demonstrar a existência de incompatibilidade de horários em cada caso específico, não bastando apenas cotejar o somatório de horas trabalhadas. Precedentes do STJ (AgRg no RMS 43.396/AP, Rel. Ministro HERMAN BENJAMIN, SEGUNDA TURMA, julgado em 07/08/2014, DJe 25/09/2014).

Também esta foi a nossa posição, na qualidade de Julgador, em caso real enviado à nossa jurisdição, verbis:

(...) Acolho o entendimento no sentido de que não se pode prejudicar a impetrante por mera presunção de que a realização de jornada de trabalho superior a sessenta horas compromete a qualidade do serviço 
prestado, uma vez que a Administração, ao longo dos dois primeiros anos em que o servidor se encontra investido no cargo público, faz, obrigatoriamente, avaliação especial de seu desempenho, por se tratar de condição para que este venha a adquirir estabilidade no serviço público.

(...)

Deve-se registrar que, de fato, por força do que dita a Súmula $n^{\circ} 16$ do STF, não poderia a apelante ter sido impedida de tomar posse no cargo em questão - para o qual foi regularmente nomeada, após aprovação no respectivo concurso público (fls. 41 e 44/45) -, devendo o requisito da compatibilidade de horários ser aferido em âmbito interno, ao longo do procedimento administrativo devido (TRF2; AC 0027260-24.2016.4.02.5101, Rel. Des. REIS FRIEDE, 6a Turma, DJE 17/08/2017).

O art. 37, XVI, "b", da Constituição Federal de 1988 garante a acumulação de um cargo de professor com outro técnico ou científico, desde que haja compatibilidade de horários. II. No caso em exame, o Impetrante juntou declarações comprovando a existência de compatibilidade de horários de maneira que não há que se falar em limitação da jornada de trabalho. Entendimento contrário implicaria, sem amparo legal, criar requisito adicional para a acumulação de cargos. III. Quanto à limitação imposta pelo Parecer AGU/GQ - 145, tanto o dispositivo constitucional supracitado, como o art. $118, \S 2^{\circ}$, da Lei $\mathrm{n}^{\circ}$ 8.112/90, mencionam apenas a compatibilidade de horários, não fazendo qualquer referência à carga horária. IV. Ademais, não se pode, por mera presunção de que a realização de jornada semanal de trabalho superior a sessenta horas comprometerá a qualidade do serviço prestado, impedir-se a cumulação em comento. (TRF2; AC 00118533220034025101, Rel. Min. REIS FRIEDE, $7^{\text {a }}$ Turma, DJE 05/06/2009)

Essa presunção somente poderá ser afastada se, no caso concreto, existirem provas de que o desempenho do agente público, em quaisquer dos cargos por ele exercidos cumulativamente, apresenta-se efetivamente comprometido pelo excesso de carga horária, posto que a norma constitucional que, excepcionalmente, admite a acumulação de cargos, é uma norma de abrangência restritiva (está restrita aos casos expressamente previstos na $\mathrm{CRFB} / 88$, à existência de compatibilidade de horários e à remuneração não superior ao teto). 
Por se tratar de norma restritiva, a interpretação deve ser também restritiva, ou seja, não é possível ampliar as limitações previstas na norma, estabelecendo outros critérios além daqueles eleitos (legitimamente) pelo constituinte.

A esse respeito, confira-se ainda parte do teor do Acórdão $\mathrm{n}^{\circ}$ 6475/2017, da Segunda Câmara do TCU, proferido em outubro de 2017 pelo Ministro BENJAMIN ZYMLER, verbis:

Entretanto, o TCU mudou o posicionamento jurisprudencial no sentido de que nas acumulações legais de acumulação de cargos públicos a compatibilidade de horários deve, sempre, ser apurada caso a caso. Havendo extrapolação da carga horária de sessenta horas semanais, a instância responsável pela análise da viabilidade da acumulação deve verificar, junto à autoridade hierarquicamente superior ao servidor, a qualidade e o não comprometimento do trabalho, fundamentando sua decisão e anexando ao respectivo processo administrativo a documentação comprobatória, conforme os Acórdãos 625/2011 - TCU - $2^{\text {a }}$ Câmara, Acórdão 2368/2012 - TCU - $2^{\text {a }}$ Câmara, Acórdão 1338/2011- TCU-Plenário, Acórdão 2368/2012 TCU - 2a . Câmara e Acórdão 1606/2012 - TCU - $1^{\text {a }}$ Câmara.

O Ministro AROLDO CEDRAZ, na prolação do Acórdão n 1.868/2010 no Plenário do TCU, em julho de 2010, trouxe importante reflexão que igualmente se amolda ao melhor deslinde do assunto em apreciação:

(...) Deve ser acrescentado, a propósito, apenas a título de registro, já que não necessário ao caso em exame, que o Tribunal, na Sessão de 6/10/2009, ao examinar pedido de reexame interposto contra decisão que considerou ilegal ato de admissão de pessoal pelo fato de a servidora exercer dois cargos com cargas horárias que somadas ultrapassavam a 60 (sessenta) horas semanais, decidiu acolher as conclusões do Revisor do processo, Ministro BENJAMIN ZYMLER, e dar provimento ao recurso, para tornar insubsistente a deliberação recorrida, conforme Acórdão 5.257/2009 - TCU - $2^{\text {a }}$ Câmara.

(...) $\mathrm{Na}$ mencionada deliberação, elastecendo-se o entendimento anteriormente firmado pela jurisprudência deste Tribunal quanto ao limite máximo de 60 (sessenta) horas para a acumulação regular de cargos públicos, ficou consignado que a licitude da acumulação de cargos não 
está sujeita a jornada máxima a ser exercida nos dois cargos acumuláveis, haja vista a inexistência de disposição legal nesse sentido, devendo a compatibilidade de horários ser verificada em cada caso.

Destarte, a licitude da acumulação de cargos não está sujeita a uma jornada máxima, haja vista a inexistência de disposição legal a respeito; a solução deve ser dada à luz do caso concreto.

Assim sendo, a aplicação da orientação firmada no Parecer Normativo AGU/GQ n 145/1998, no sentido de que o limite aceito pela administração pública federal para permitir a acumulação de cargos seria de 60 horas semanais, não pode ser desprovida de uma análise aprofundada de cada caso específico, sob pena de se incorrer em distorções e interpretações enviesadas das regras constitucionais.

\section{DO REGIME DE TRABALHO DO PROFESSOR DE ENSINO SUPERIOR}

Registre-se que está excluído da presente abordagem o caso específico do professor em regime de dedicação exclusiva, pois, nessa hipótese, ainda que haja compatibilidade de horários, não poderá haver acumulação, mormente considerando que o servidor nesta situação recebe um adicional a título de Dedicação Exclusiva.

Será tomado como parâmetro para este artigo, portanto, a exclusiva hipótese do professor que labora em regime de 40 horas semanais.

No entanto, cabe salientar, em necessária adição explicativa, que é permitida a acumulação de cargo de professor em regime de dedicação exclusiva com proventos de aposentadoria de outro cargo de Professor. É intuitivo que não há incompatibilidade de horários se o servidor já se encontra aposentado em um dos cargos. Neste sentido, confira-se:

Hipótese em que a autora pretende ver reconhecido o direito de permanecer no cargo de professora, com jornada de trabalho de 40 horas semanais, continuando a receber proventos de aposentadoria de forma integral, por ter se aposentado em outro cargo de professora, com a mesma carga horária. (...) Segundo orientação da Suprema Corte, é impertinente a exigência de compatibilidade de horários como requisito para a percepção simultânea de um provento de aposentadoria com a remuneração pelo 
exercício de outro cargo público. (Precedentes do Pretório Excelso: RE 547731 AgR, Relator(a): Min. EROS GRAU, Segunda Turma, DJe 31.07.2008 e RE 701999 AgR, Rel. Min. RICARDO LEWANDOWSKI, Segunda Turma, julgado em 02/10/2012, DJe 19.10.2012). (STJ; AgRg no AREsp 415.292/SC, Rel. Min. MAURO CAMPBELL MARQUES, $2^{\text {a }}$ Turma, DJE 10/12/2013)

A acumulação de dois cargos de professor - um cargo inativo com outro em atividade - não viola do disposto no artigo 37, XVI, da Constituição do Brasil. Não há incompatibilidade de horários se a servidora já se encontra aposentada em um dos cargos. (STF; RE 547731 AgR, Rel. Min. EROS GRAU, $2^{\mathrm{a}}$ Turma, DJE 17/06/2008)

É firme a orientação desta Corte de que é permitida a acumulação de cargo de Professor em regime de dedicação exclusiva com proventos de aposentadoria de outro cargo de Professor. Precedentes: AgRg no AREsp. 548.537/PE, Rel. Min. BENEDITO GONÇALVES, DJe 5.3.2015; AgRg no RMS 30.143/SC, Rel. Min. ADILSON VIEIRA MACABU, DJe 9.8.2012 e AgRg no AgRg no REsp. 817.168/RJ, Rel. Min. OG FERNANDES, DJe 3.8.2011. (STJ; AgRg no RMS 35.619/ SC, Rel. Min. NAPOLEÃO NUNES MAIA FILHO, $1^{\text {a }}$ Turma, DJe 27/05/2016)

\subsection{Diferença entre hora-aula e hora efetiva}

Preliminarmente, é de suma importância a distinção entre hora-aula e hora efetiva.

Como se sabe, "hora" é o período de 60 (sessenta) minutos, em convenção consagrada pela civilização contemporânea. Já a definição quantitativa em minutos do que consiste a hora-aula é uma atribuição das Instituições de Educação Superior, desde que feita sem prejuízo ao cumprimento das respectivas cargas horárias totais dos cursos, e está referenciada às questões de natureza trabalhista e, sobretudo, remuneratória.

Destarte, embora a carga horária mínima dos cursos superiores seja mensurada em horas efetivas (60 minutos), tal período se refere a atividades acadêmicas e de trabalho discente efetivo, não somente (e necessariamente) em sala de aula, e, mesmo quando assim compreendidas, estas são computadas em horas-aula (de 50 minutos de duração). 
Aliás, a Lei no 9.394/96 dispõe em seu artigo 57 que, nas instituições públicas de educação superior, o professor ficará obrigado ao cumprimento real de apenas um mínimo de oito horas semanais de aulas.

O Conselho Federal de Educação, órgão normativo que inclui na sua esfera de competência e de atribuições estabelecer a duração e o currículo mínimo dos cursos de ensino superior (Lei no 4.024/61, art. 9ª, parágrafo $\left.1{ }^{\circ}, " \mathrm{e} "\right)$, em diversos e conhecidos pronunciamentos, consagrou como duração da hora-aula o tempo de cinquenta (50) minutos, com um intervalo de dez (10) minutos, para descanso dos alunos, entre uma hora-aula e outra.

Outrora, a Portaria no 204/45 do MEC dispunha que nos estabelecimentos que ministrassem ensino de grau superior ou médio, as aulas diurnas seriam de 50 (cinquenta) minutos, e as aulas noturnas de 40 (quarenta) minutos. No entanto, conforme entendimento do STF, a mesma se revela incompatível com a norma constitucional superveniente que atribui o poder normativo à Justiça do Trabalho, sendo que a derrogação alcança a dinâmica do ato, resguardados os efeitos produzidos até o momento em que ele se tornou incompatível com a norma constitucional (STF; RR $n^{\circ}$ 3.867/78, Rel. Min. COQUEIJO COSTA, 3 ${ }^{a}$ Turma, DJU de 25/05/1979. No mesmo sentido: TST; RR n 6.354/88.8, Rel. Min. JOSÉ AJURICABA, $2^{\mathrm{a}}$ Turma, DJU, Seção I, 26/10/1990).

Por outro lado, o Decreto $n^{\circ} 5.773 / 06$, que trata especificamente sobre a educação superior no sistema federal de ensino, prevê, no parágrafo único do artigo 69, que o regime de trabalho docente em tempo integral compreende a prestação de quarenta horas-aula (de 50 minutos de duração) semanais de trabalho na mesma instituição (porém, não necessariamente com a efetiva presença do professor nas instalações físicas), nele reservado o tempo mínimo de, pelo menos, 20 horas-aula semanais para estudos, pesquisa, trabalhos de extensão, planejamento e avaliação.

Com base nesses preceitos, o que se pode, sem muito esforço analítico, deduzir é que, se o educador foi empossado em um cargo com 40 horas semanais, não significa em absoluto que o mesmo permanecerá todo este período apenas dentro da sala de aula e, mais, que seu regime laboral é computado não com base em uma hora de 60 minutos (hora efetiva) e sim de uma hora-aula de 50 minutos.

Cabe às Instituições de Educação Superior, respeitado o mínimo dos duzentos dias letivos de trabalho acadêmico efetivo, a definição da duração da atividade acadêmica ou do trabalho discente concreto, que 
compreenderá preleções, aulas expositivas, atividades práticas supervisionadas, tais como laboratórios, atividades em biblioteca, iniciação científica, trabalhos individuais e em grupo, práticas de ensino e outras atividades no caso das licenciaturas, conforme dispõe a Resolução n 3/2007 do Ministério da Educação.

Ou seja, a presença física desse professor na Universidade é exigida apenas em média por 12 horas-aula semanais. As 28 horas-aulas restantes se referem a atividades fora da sala de aula, como aquelas pertinentes à elaboração e correção de provas e avaliações dos alunos, à preparação de aulas a serem ministradas e ao estudo, atualização e pesquisa dos temas a serem abordados, dentre tantas outras. Tais atividades podem ser desenvolvidas em casa, com absoluta liberdade de programação, utilizando, inclusive, os sábados, domingos e feriados.

O professor do CAHL - Centro de Artes, Humanidades e Letras da Universidade Federal do Recôncavo da Bahia, FABRÍCIO LYRIO, questionou, em evento da Associação dos Professores Universitários do Recôncavo (APUR), - que luta para que seja assegurado o direito à carga horária mínima de oito horas-aula em atividades de sala de aula -, a tese segundo a qual se o ensino, a pesquisa e a extensão têm o mesmo valor, por que o ensino deveria ocupar mais de um terço da carga horária, considerando que existem outras atividades desempenhadas pelos professores, que vão além das referentes à sala de aula propriamente dita (Disponível em: <https://goo.gl/tqaujp>. Acesso em: 02 fev. 2018).

Sendo assim, a AGU ignorou o fato de que a carga horária dos profissionais da educação é destinada, também, para pesquisa, atendimento aos alunos, resolução de trabalhos e provas, tornando até mesmo possível o cumprimento teórico das permitidas (porém, equivocadas) 80 horas semanais, uma vez que não são cumpridas na sala de aula e no estabelecimento de ensino.

Mas, também desconsiderou (o que é mais grave ainda) que o cômputo do tempo laboral do professor é realizado em hora-aula (com 50 minutos de duração) e não em hora efetiva (com 60 minutos de duração). Assim sendo, mesmo que um professor fosse obrigado a cumprir seu regime de trabalho de 40 horas, integralmente em sala de aula e no estabelecimento de ensino, sua carga horária efetiva seria, em termos reais, de 33 horas, o que totalizaria, em qualquer hipótese de acumulação de cargos, valor inferior a 80 horas efetivas. 
Cabe esclarecer que a Administração dispõe de instrumentos que permitem o cruzamento de dados entre instituições, os quais instrumentalizam ao órgão a identificação de situações de acúmulo de cargos. Assim sendo, constatada alguma irregularidade, o órgão de vinculação do servidor é notificado, levando ao conhecimento do servidor as constatações, devendo este adotar as providências cabíveis à situação apurada e apresentar esclarecimentos, razão pela qual, também sob este prisma analítico, a limitação de carga horária, além de descabida no caso do Magistério, é flagrantemente inconstitucional.

Vale reafirmar que, em termos reais, a carga horária real, no caso de acumulação de profissional com regime de 40 horas laborais com o cargo de professor em regime de 40 horas-aula (33 horas efetivas), somente pode ser computado (em simples soma aritmética) com as 12 horas-aula (10 horas efetivas) máximas, exigidas em sala de aula e com a presença física do professor no estabelecimento de ensino, o que totaliza, na prática, apenas 50 horas de efetivo exercício laboral presencial.

\subsection{Do Sistema Diferenciado para o Cargo de Magistério}

Partindo da interpretação teleológica, que contempla o elemento finalístico da norma, ou seja, o fim para o qual ela foi elaborada, pode-se perceber que a autorização constitucional para o acúmulo de cargos de professor "num primeiro momento, (...) pretendeu fomentar a educação no País, e, num segundo momento, ao autorizar a acumulação remunerada de um cargo de professor com outro cargo técnico ou científico (art. $37, \mathrm{XVI}, \mathrm{b}$ ), visou salvaguardar a própria sobrevivência do docente, dado o baixo nível dos vencimentos (todos sabem) que os profissionais do magistério sempre auferiram no Brasil" (MAZZUOLl; ALVES, 2013, p. 91).

Além de ser inconstitucional a limitação da jornada, - considerando que constitui um novo critério para a acumulação de cargos públicos previsto em ato sem força normativa suficiente para tanto -, não se apresenta minimamente razoável, sobretudo ao singelo, reducionista e equivocado argumento de que o servidor, neste caso, teria uma jornada humanamente impossível de se cumprir, haja vista que, na realidade, a acumulação no regime de 40 horas-aula, em termos de presença física no estabelecimento de ensino, não é obrigatória, além das 12 horas-aula (10 horas efetivas). 
Em necessária adição argumentativa, vale repisar que, regra geral, a hora-aula dos professores contabiliza 50 (cinquenta) minutos. Dita estipulação por si só já torna a jornada do servidor que exerce o magistério, diferenciada. Afora o tempo reservado para outras atividades docentes, o que está (ou deveria estar) incluído na carga horária. Tais premissas decorrem do comando legal instituído pelo artigo 67, inciso V da Lei n 9.394/96 (Lei de Diretrizes e Bases da Educação Nacional).

Em virtude disto, há professores que, apesar de possuírem carga horária de 40 horas-aula semanais (e da existência do comando normativo que exige apenas 12 horas-aula semanais em sala de aula e no estabelecimento de ensino), excepcionalmente, por ato voluntário, lecionam (ou permanecem no estabelecimento de ensino) em 20 dessas horas-aula, sobrando outras 20 horas para pesquisa, estudo, correção de provas e trabalhos, que podem ser usadas no momento mais adequado ao servidor, ficando ao seu critério escolhê-lo, totalizando um regime real laboral de 16,5 horas efetivas, que adicionadas às 40 horas semanais de sua atividade técnico-científica, somam menos de 57 horas totais.

Quanto ao restante do tempo a que está sujeito em função de seu regime laboral de 40 horas-aula (33 horas efetivas), ou seja, as demais 20 horas-aula (16,5 horas efetivas) vale reafirmar que existe a possibilidade corriqueira do servidor utilizar esse tempo restante em casa, aos sábados, domingos ou em outros dias de folga (feriados de modo geral), o que reforça a ideia da absoluta possibilidade de exercício de uma jornada cumulável, sem necessariamente se tornar desgastante fazê-la.

Ora, se a lei não estabeleceu abstrata e expressamente o limite da carga horária passível de acumulação, não pode o intérprete inovar o ordenamento jurídico mediante a criação de uma limitação abstrata, surpreender os cidadãos destinatários da norma. Assim, pode um professor com regime de $40 \mathrm{~h}$ semanais cumular outro cargo de professor com regime também de $40 \mathrm{~h}$ semanais (...) (MAZZUOLl; ALVES, 2013, p. 94).

Como bem pontuou o Ministro FERNANDO EIZO ONO "o fato de a Constituição Federal limitar a oito horas diárias e 44 horas semanais a jornada laboral não autoriza a limitação de jornada a sessenta horas semanais nos casos de cumulação de cargo e emprego público, visto que a limitação a $44 \mathrm{~h}$ semanais se refere à limitação dirigida ao empregador de 
exigir labor excedente em razão de uma única relação de emprego, nada dispondo sobre jornada nas hipóteses de cumulação de cargos ou empregos públicos" (TST; AIRR - 1693-31.2012.5.09.0872, Rel. Min. FERNANDO EIZO ONO, 4a Turma, DJE 10/12/2014).

\section{3 Da Acumulação dos Cargos de Magistério e Magistratura}

É estreita, para não dizer restrita ao magistério superior, a possibilidade legal do exercício de outra atividade remunerada por integrantes da magistratura. Na Constituição Federal de 1946, a vedação aos Magistrados para o exercício de outra função era disciplinada desta forma:

Art 96. É vedado ao Juiz:

I - exercer, ainda que em disponibilidade, qualquer outra função pública, salvo o magistério secundário, e superior e os casos previstos nesta Constituição, sob pena de perda do cargo judiciário.

Em 1967, essa redação foi alterada, substituindo-se o artigo definido "o" pelo artigo indefinido "um":

Art 109. Exercer, ainda que em disponibilidade, qualquer outra função pública, salvo um cargo de magistério e nos casos previstos nesta Constituição.

$\mathrm{Na}$ CRFB/88, essa última fórmula adotada pela Constituição de 1967 foi repetida. Com efeito, o inc. I do parágrafo único do art. 95 da Constituição Federal proíbe ao magistrado, ainda que em disponibilidade, a acumulação de outro cargo ou função, salvo uma de magistério público, verbis:

Parágrafo único. Aos juízes é vedado:

I - exercer, ainda que em disponibilidade, outro cargo ou função, salvo uma de magistério;

A Lei Orgânica da Magistratura (Lei Complementar nº 35 de 1979), em seus artigos 26 e 36, na mesma linha, também prevê a mesma possibilidade restrita de acumulação, mas vai além, ao exigir a correlação de matérias e a compatibilidade de horários, explicitando que é vedado, em qualquer hipótese, o desempenho de função de direção administrativa ou técnica, proibição na qual se inclui, intuitivamente, tais funções prestadas em estabelecimentos de ensino. 
Posteriormente foi expedida a Resolução n 34 , de 24 de abril de 2007, dispondo sobre o exercício de atividades de magistério pelos integrantes da magistratura nacional, verbis:

Art. $1^{\circ}$ Aos magistrados da União e dos Estados é vedado o exercício, ainda que em disponibilidade, de outro cargo ou função, salvo o magistério.

Parágrafo único. O exercício da docência por magistrados, na forma estabelecida nesta Resolução, pressupõe compatibilidade entre os horários fixados para 0 expediente forense e para a atividade acadêmica, o que deverá ser comprovado perante o Tribunal.

Art. $2^{\circ} \mathrm{O}$ exercício de cargos ou funções de coordenação acadêmica, como tais considerados aqueles que envolvam atividades estritamente ligadas ao planejamento e/ou assessoramento pedagógico, será admitido se atendidos os requisitos previstos no artigo anterior.

$\S 1^{\circ}$ É vedado o desempenho de cargo ou função administrativa ou técnica em estabelecimento de ensino.

$\S 2^{\circ} \mathrm{O}$ exercício da docência em escolas da magistratura poderá gerar direito a gratificação por hora-aula, na forma da lei.

$\S 3^{\circ}$ Não se incluem na vedação referida no $\S 1^{\circ}$ deste artigo as funções exercidas em curso ou escola de aperfeiçoamento dos próprios Tribunais, de associações de classe ou de fundações estatutariamente vinculadas a esses órgãos e entidades.

(...)

Art. $4^{\circ} \mathrm{A}$ presente resolução aplica-se inclusive às atividades docentes desempenhadas por magistrados em cursos preparatórios para ingresso em carreiras públicas e em cursos de pós-graduação.

Art. $4^{\circ}-\mathrm{A}$ A participação de magistrados na condição de palestrante, conferencista, presidente de mesa, moderador, debatedor ou membro de comissão organizadora, inclusive nos termos do art. $4^{\circ}$ da Resolução CNJ 170/2013, é considerada atividade docente, para os fins desta Resolução. (Incluído pela Resolução n 226, de 14.06.16)

(...)

$\S 3^{\circ} \mathrm{A}$ atuação dos magistrados em eventos aludidos no caput deste artigo deverá observar as vedações constitucionais relativamente à magistratura (art. 95, parágrafo único, da Constituição), cabendo aojuiz zelar para 
que essa participação não comprometa a imparcialidade e a independência para o exercício da jurisdição, além da presteza e da eficiência na atividade jurisdicional. (Incluído pela Resolução $n^{\circ} 226$, de 14.06.16)

Art. $5^{\circ}$ Os Tribunais deverão disponibilizar em seu sítio eletrônico base de dados com as informações indicadas no art. $3^{\circ}$ e no $\S 1^{\circ}$ do art. $4^{\circ}-\mathrm{A}$, acessível a qualquer interessado, consoante as determinações da Resolução CNJ 215/2015, inclusive para os fins de aferição de situações de impedimento, nos termos do art. 144, VII, do Código de Processo Civil. (Redação dada pela Resolução $n^{\circ} 226$, de 14.06.16)

Parágrafo único. Caso o magistrado não reconheça seu impedimento para atuar no processo, nas hipóteses previstas nesta Resolução, a parte interessada poderá promover a respectiva arguição nos termos da lei processual correspondente. (Incluído pela Resolução $n^{\circ}$ 226, de 14.06.16)

Art. $5^{\circ}$-A As atividades de coaching, similares e congêneres, destinadas à assessoria individual ou coletiva de pessoas, inclusive na preparação de candidatos a concursos públicos, não são consideradas atividade docente, sendo vedada a sua prática por magistrados. (Incluído pela Resolução $n^{\circ}$ 226, de 14.06.16)

Já a Resolução n 170/2013 regulamentou a participação de magistrados em congressos, seminários, simpósios, encontros jurídicos e culturais e eventos similares, privados, verbis:

Art. $1^{\circ}$ Os congressos, seminários, simpósios, encontros jurídicos e culturais e eventos similares realizados, promovidos ou apoiados pelos Conselhos da Justiça, Tribunais submetidos à fiscalização do Conselho Nacional de Justiça e Escolas Oficiais da Magistratura, estão subordinados aos princípios de legalidade, impessoalidade, moralidade, publicidade e eficiência, de forma que o conteúdo do evento, sua carga horária, a origem das receitas e o montante das despesas devem ser expostos de forma prévia e transparente.

Art. $2^{\circ}$ Os congressos, seminários, simpósios, encontros jurídicos e culturais e eventos similares, quando promovidos por Tribunais, Conselhos de Justiça e Escolas Oficiais da Magistratura, com participação de magistrados, podem contar com subvenção de entidades 
privadas com fins lucrativos, desde que explicitado o montante do subsídio e que seja parcial, até o limite de $30 \%$ dos gastos totais.

Art. $3^{\circ}$ A documentação relativa aos congressos, seminários, simpósios, encontros jurídicos e culturais e eventos similares, quando realizados por órgãos da justiça submetidos ao Conselho Nacional de Justiça, inclusive as Escolas Oficiais da Magistratura, ficará à disposição do CNJ para controle, bem como de qualquer interessado.

Art. $4^{\circ} \mathrm{A}$ participação de magistrados em encontros jurídicos ou culturais, quando promovidos ou subvencionados por entidades privadas com fins lucrativos, e com transporte e hospedagem subsidiados por essas entidades, somente poderá se dar na condição de palestrante, conferencista, presidente de mesa, moderador, debatedor ou organizador. Parágrafo único. A restrição não se aplica aos eventos promovidos e custeados com recursos exclusivos das associações de magistrados.

Art. $5^{\circ}$ Ao magistrado é vedado receber, a qualquer título ou pretexto, prêmios, auxílios ou contribuições de pessoas físicas, entidades públicas ou privadas, ressalvadas as exceções previstas em lei.

Destarte, podemos concluir que a participação de magistrados como palestrantes, conferencistas, presidentes de mesa, moderadores, debatedores ou membros de comissão organizadora, são considerados atividade de docência; enquanto que o serviço de coaching e similares, voltados à preparação de candidatos para concursos públicos, passou a ser vedado, conforme entendimento firmado pelo CNJ.

No que se refere à Resolução no 336/2003, cabe tecer algumas considerações. Ao disciplinar sobre o acúmulo do exercício da magistratura com o exercício do magistério no âmbito da Justiça Federal de primeiro e segundo graus, a referida norma dispôs que ao Juiz é defeso o exercício de outro cargo ou função, ressalvado(a) um(a) único(a) de magistério, público ou particular.

No entanto, a expressão "único(a)" está com sua eficácia suspensa por força de liminar concedida pelo STF nos autos da ADI n 3.126. Confira-se:

Ação Direta de Inconstitucionalidade ajuizada contra a Resolução n 336, de 2.003, do Presidente do Conselho da Justiça Federal, que dispõe sobre o acúmulo do exercício 
da magistratura com o exercício do magistério, no âmbito da Justiça Federal de primeiro e segundo graus. 2. Alegação no sentido de que a matéria em análise já encontra tratamento na Constituição Federal (art. 95, parágrafo único, I), e caso comportasse regulamentação, esta deveria vir sob a forma de lei complementar, no próprio Estatuto da Magistratura. 3. Suposta incompetência do Conselho da Justiça Federal para editar o referido ato, porquanto fora de suas atribuições definidas no art. 105, parágrafo único, da Carta Magna. 4. Considerou-se, no caso, que o objetivo da restrição constitucional é o de impedir o exercício da atividade de magistério que se revele incompatível com os afazeres da magistratura. Necessidade de se avaliar, no caso concreto, se a atividade de magistério inviabiliza o ofício judicante. 5. Referendada a liminar, nos termos em que foi concedida pelo Ministro em exercício da presidência do Supremo Tribunal Federal, tão-somente para suspender a vigência da expressão "único (a)", constante da redação do art. $1^{\circ}$ da Resolução $n^{\circ} 336 / 2003$, do Conselho de Justiça Federal.

Merece ser transcrito o relatório do Ministro NELSON JOBIM na decisão proferida na mencionada Ação Declaratória de Inconstitucionalidade $n^{\circ} 3.126$, que de todo modo corrobora o que aqui se está defendendo, verbis:

Ao usar, na ressalva, a expressão 'uma de magistério', tem a CF, por objetivo, impedir que a cumulação autorizada prejudique, em termos de horas destinadas ao magistério, o exercício da magistratura. Daí a restrição à unidade ('uma de magistério'). A Constituição Federal, ao que parece, não impõe o exercício de uma única atividade de magistério. O que impõe é o exercício de atividade do magistério compatível com a atividade de magistrado. A fixação ou a imposição de que haja apenas uma 'única' função de magistério, - preconizada na Resolução (Resolução no 336 de 2003) -, ao que tudo indica, não atende o objetivo constitucional.

A questão está no tempo que o magistrado utiliza para o exercício do magistério vis a vis ao tempo que restaria para as funções judicantes. Poderá o magistrado ter mais de uma atividade de magistério - considerando diferentes 
períodos letivos, etc. - sem ofensa ao texto constitucional. Impor uma única e só função ou cargo de magistério não atende, necessariamente, ao objetivo constitucional.

(...)

Ou, ainda, que um magistrado-docente, titular de um único cargo em universidade federal - professor adjunto ministre aulas na graduação, no mestrado e no doutorado (simultaneamente). Nestas hipóteses, mesmo sendo um único cargo, ter-se-ia a burla da regra constitucional. Poderá ocorrer e, certamente, ocorre que o exercício de mais de uma função no magistério não importe em lesão ao bem privilegiado pela Constituição Federal - o exercício da magistratura. A questão é (fundamentalmente) a compatibilização de horários, que se resolve caso a caso. (...)

Creio que a regra básica da Resolução (Resolução n 336 de 2003) está no seu art. $2^{\circ}$. Este só admite o exercício da docência "(...) se houver compatibilidade de horário com o trabalho judicante." Aqui não há qualquer conflito com a Constituição Federal. Pelo contrário. A Resolução (Resolução no 336 de 2003), neste art. $2^{\circ}$, instrumentaliza a regra constitucional.

Em seu voto na citada ADI, o Ministro GILMAR MENDES expôs com propriedade que, verbis:

A interpretação adotada por JOBIM quanto ao art. $1^{\circ}$ é particularmente acertada. O objetivo da restrição constitucional é o de impedir o exercício da atividade de magistério que se revele incompatível com os afazeres da magistratura. O que importa, de fato, é o tempo utilizado pelo magistrado para o exercício do magistério em face do tempo reservado à atividade judicante. Um magistrado poderia assumir, por exemplo, com uma única instituição, uma carga horária de quarenta horas-aula, enquanto outro poderia, perante duas ou três instituições diferentes, assumir atividade docente que, em sua totalidade, não exceda a vinte horas semanais. Em tese, esse segundo magistrado teria mais tempo livre para a atividade de juiz, mas essa também sequer é uma conclusão necessária.

O que importa, em suma, é saber se a atividade de magistério está, no caso concreto, inviabilizando o ofício judicante. 
Dessa forma, o Plenário do STF referendou, por maioria, a liminar concedida pelo Ministro NELSON JOBIM, em janeiro de 2004, na Ação Direta de Inconstitucionalidade (ADI) 3.126, proposta pela Associação dos Juízes Federais do Brasil (Ajufe) contra a Resolução n 336/03, do CJF. A decisão, portanto, permite ao juiz exercer mais de uma atividade de magistério, desde que compatível com o exercício da magistratura.

Devemos sublinhar, outrossim, o posicionamento do Procurador Geral do Ministério Público no Acórdão no 1.751/2006/Plenário TCU, quando afirma que, inexistindo prejuízo concreto às respectivas funções, a acumulação de cargos legalmente permitida, sem carga horária rígida para o fim de exercício do magistério.

No meu entender, a questão da incompatibilidade de horários deve, sempre, ser estudada caso a caso. A situação dos servidores do TRF $2^{\text {a }}$ Região ora arrolados nos autos não pode ser comparada, por exemplo, à situação de servidores de outros órgãos da administração pública que, regimentalmente, estão obrigados a cumprir jornada diária de trabalho em dois turnos (matutino e vespertino), para os quais resta somente o período noturno para atividades de magistério. (...) Todavia, este não é o caso dos servidores do TRF $2^{\text {a }}$ Região que, como afirmei acima, possuem, em regra, dois turnos por dia (matutino e noturno) para atividades externas ao Tribunal. Além disso, é notório que o regime de quarenta horas de um professor não é cumprido integralmente em sala de aula e, sendo assim, as horas complementares podem ser cumpridas a qualquer hora do dia ou da noite e em qualquer dia da semana. Com muito mais razão, eu defenderia a situação dos juízes daquele tribunal federal, pois nem mesmo possuem jornada fixa diária de trabalho, podendo desenvolver sua função judicante, inclusive, nos finais de semana, como notoriamente não é raro de se observar. O acúmulo de cargos por juízes pode ser desenvolvido sem restrições de horário, pois eles não possuem jornada semanal fixa e seus cronogramas de atividades podem ser adequados de forma a que possam destinar grande parte de seu tempo ao magistério. (...) Em reforço a essa tese, é certo que o CNJ, ao tratar dessa questão, não restringe o desempenho da atividade de magistério por juízes a regimes de 20 horas semanais. Da mesma forma por mim ora defendida, aquele Conselho prevê que a análise da carga horária semanal deve ser examinada caso a caso, 
para fins de verificação da compatibilidade de horários entre as atividades em comento.

(...)

De acordo com os dispositivos acima transcritos e por todo o exposto, não se pode concluir pela irregularidade das acumulações de cargo relacionadas nos autos, nos casos em que o exercício do cargo de servidor ou de juiz do TRF $2^{\text {a }}$ Região esteja acumulado com apenas um cargo de professor, ainda que em regime de 40 horas semanais.

Assim, como consignamos alhures, a CRFB/88 não impõe uma única atividade de magistério, mas sim o exercício desta função compatível com a de magistrado, para impedir que a acumulação autorizada prejudique, em termos de horas destinadas ao ensino, o exercício da magistratura, sendo inconteste a jurisprudência consolidada do STF no sentido da absoluta licitude da acumulação do cargo de Juiz com o de professor em regime laboral de 40 horas-aula, podendo o magistrado assumir, por exemplo, com uma única instituição, uma carga horária de 40 horas-aula.

\section{DA IMPORTÂNCIA DO CARGO EXERCIDO PELO PROFESSOR ALÉM DO MAGISTÉRIO}

Especificamente no tocante a Faculdades de Direito, é igualmente essencial que o corpo docente seja composto, outrossim, de profissionais que exerçam as suas funções, na prática, como Juízes, Promotores, Delegados e Advogados, e não apenas e exclusivamente por professores meramente teóricos ou acadêmicos.

É uma relação fundamental em que todos ganham com a experiência. Afinal, muitas sentenças, inquéritos, demandas servem de exemplo em sala de aula, e muitas aulas preparadas podem servir de base para um julgamento.

A experiência da prática jurídica traz indubitavelmente uma visão multidisciplinar e uma formação metodológica hábil ao tratamento e ensino de qualquer ramo do Direito.

Destarte, não se vislumbra a priori qualquer prejuízo aos alunos ou ao mestre, na acumulação do cargo público referente à área jurídica com outro de magistério, mormente considerando as especificidades que norteiam o ofício de ensinar. Tanto assim, que diversos Magistrados acumulam o exercício da judicatura com a docência, inclusive submetidos ao 
expediente de 40 horas semanais, sem qualquer prejuízo a nenhum dos dois cargos.

Embora exista precedente do Tribunal Regional Federal inadmitindo, por exemplo, a acumulação dos cargos de Delegado Federal e professor que trabalhe sob o regime de 40 horas semanais, data maxima venia, faltou uma imprescindível densidade cognitiva no exame da questão, que, de modo superficial, simplesmente somou as cargas horárias (sem atentar às singularidades da carga horária docente, computada legalmente em horas-aula de 50 minutos e nos limites de 12 horas-aula ou 10 horas efetivas no estabelecimento de ensino) para aferir a compatibilidade de horários. Idêntico equívoco foi também cometido pelo Parecer Normativo AGU/GQ n 145/1998, posto que não se pode olvidar que o Princípio da Isonomia significa tratar situações diferentes de modo diferente, exatamente em busca de justiça.

Portanto, entende-se que diversos objetivos serão preservados e conciliados se Juízes, Promotores, Delegados, Procuradores, Servidores e daí por diante, possam exercer o magistério, aferindo-se a compatibilidade de horários caso a caso, dos quais podemos citar:

1) o interesse público coletivo, pois permitirá que Juízes, Promotores, Delegados, Procuradores, Servidores e daí por diante, detentores de notória experiência, possam difundir a estudantes seus conhecimentos práticos, sem limitações de carga horária, desde que não haja incompatibilidade de horário e prejuízo às atividades exercidas em cada um dos cargos licitamente acumulados.

2) o interesse individual dos envolvidos, vez que Ihes possibilitará o exercício de atividades práticas (magistratura e demais cargos públicos) e teóricas (magistério), as quais, ao final, se fundem e se complementam, em pleno aprimoramento do interessado, e mais importante, resultará em benefícios à sociedade que lhes remunera.

3) o cumprimento de dispositivos legais e constitucionais aplicáveis à espécie, considerando que, literalmente, a acumulação de cargos não se sujeita à jornada máxima, mas apenas à comprovação de compatibilidade de horários, desde que isso não interfira no exercício, com eficiência, dos cargos licitamente acumulados.

4) o respeito à "discricionariedade" e a "subjetividade" dos dirigentes a que respondem "hierarquicamente" os servidores, no sentido de que, àqueles é possível decidir, com mais propriedade, se estes estão realizando suas atribuições profissionais com zelo, dedicação, assiduidade 
e pontualidade, conforme previsto na legislação que rege os cargos que ocupam, a rigor de forma regular.

Revela notar que aqui não se está explanando sobre os casos de acumulação de dois cargos públicos na área da saúde, inclusive porque, nestes casos específicos, o regime laboral é computado em horas efetivas e presenciais nos respectivos estabelecimentos hospitalares, em situação diametralmente diversa das hipóteses de acumulação docente. Também resta consignar que o objetivo deste artigo reside restritivamente em defender que a compatibilidade de horários não pode ficar adstrita ao simples somatório de horários, e sim, à situação específica de cada profissional com suas correspondentes singularidades.

\section{CONCLUSÃO}

Surgida com forma de garantir a moralidade e a eficiência no âmbito da Administração Pública, a vedação, em regra, de acumulação de cargos tem como objetivos resguardar o bom desempenho das atividades a serem executadas pelo servidor e garantir ao maior número possível de cidadãos habilitados para tanto o acesso aos cargos públicos.

A regra é que a acumulação de cargos é vedada. Entretanto, algumas exceções estão previstas em lei, entre as quais a acumulação de cargos de professor com outro técnico ou científico, independentemente da existência de relação das atribuições do cargo com a disciplina lecionada, desde que observada a compatibilidade de horários.

Verifica-se que a acumulação ilegal de cargos públicos nem sempre está sujeita à incidência da Lei de Improbidade Administrativa, uma vez que nos casos em que não há a comprovação do dano causado ao erário, existe apenas uma situação de irregularidade. Considerando-se como regra o pressuposto de que a boa-fé do servidor é presumida, só se admitindo a existência de má-fé quando a acumulação se der de maneira que cause efetivo dano ou prejuízo à Administração Pública.

O STJ firmou sólida jurisprudência no sentido de que, havendo comprovação de que os serviços foram efetivamente prestados, não há que se falar em desvio ético capaz de ensejar a aplicação das penas da Lei de Improbidade Administrativa. Destaque-se que, ao adotar tal entendimento, a Corte não está consentindo com a acumulação ilícita de cargos, pois existem outros instrumentos jurídicos à disposição da Administração para que se restabeleça a legalidade. 
Por outro lado, o exame aprofundado da controvérsia nos revela diversos pontos importantes que mereceram destaque: 1) a compatibilidade prevista na norma constitucional refere-se unicamente à impossibilidade de sobreposição de jornadas; 2) a limitação das horas trabalhadas semanalmente em 60 (sessenta) horas, em caso de acumulação de cargos, é ilegal e inconstitucional, seja ante a ausência de previsão na CRFB/88 e em Leis em sentido estrito, seja em virtude do princípio da hierarquia das normas; 3 ) com mais razão, tal critério de limitação da jornada semanal não poderia ser aplicado ao magistério, em virtude das especificidades da função, que é regida em regime peculiar de hora-aula com 50 minutos de duração e com exigência de menos de um terço em sala de aula e com presença física no estabelecimento de ensino.

Por toda essa sorte de considerações, conclui-se que o problema da massificação de demanda judiciais, que ocorre também na questão da acumulação de cargos por servidores públicos, são as pseudo (e, portanto, falsas) similitudes de casos que apenas aparentemente apresentam-se iguais, a exigir a mesma solução jurídica.

Destarte, é fundamental não somente a profundidade analítica, mas igualmente a densidade cognitivo-hermenêutica, especialmente em questões complexas como a acumulação de cargos públicos.

\section{REFERÊNCIAS}

CRETELLA JÚNIOR, José. Comentários à Constituição 1988. Rio de Janeiro, Forense Universitária, 1991.

MAZZUOLI, Valério; ALVES, Waldir. Acumulação de Cargos Públicos: uma questão de aplicação da Constituição. São Paulo, Editora Revista dos Tribunais, 2013.

MEIRELLES, Hely Lopes. Direito Administrativo Brasileiro. 34. ed. Atual. São Paulo: Malheiros, 2008.

SANTOS, Luan Mesan Grossmann Mendes dos. Jurisprudência: servidores públicos: acúmulo de cargos. 2017. Disponível em: <https://goo.gl/ ZWWxeE>. Acesso em: 31 jan. 2018. 